\title{
PENGARUH SELF-EXPRESSION DAN BRAND TRUST TERHADAP ELECTRONIC-WORD OF MOUTH DENGAN BRAND LOVE SEBAGAI MEDIASI PADA KONSUMEN VANS DI JAKARTA
}

\author{
Emilia Machado1, Rodhiah ${ }^{2 *}$ \\ ${ }^{1}$ Program Studi Manajemen Fakultas Ekonomi dan Bisnis, Universitas Tarumanagara \\ Email: emilia.115160209@stu.untar.ac.id \\ ${ }^{2}$ Program Studi Manajemen Fakultas Ekonomi dan Bisnis, Universitas Tarumanagara \\ *Email: rodhiah@fe.untar.ac.id \\ *penulis korespondensi
}

Masuk : 25-10-2020, revisi: 22-12-2020, diterima untuk diterbitkan : 03-01-2020

\begin{abstract}
ABSTRAK
Tujuan dari penelitian ini adalah untuk menguji dan menentukan pengaruh ekspresi diri, kepercayaan merek terhadap elektonik pemasaran merek dari mulut ke mulut dengan kecintaan pada merek sebagai mediasi. Desain penelitian yang digunakan dalam penelitian ini adalah metode kuantitatif dengan pendekatan deskriptif. Pengambilan sampel dilakukan menggunakan metode non-probability sampling dengan Teknik pendekatan convenience sampling. Diteliti sebanyak 100 responden yang merupakan konsumen Vans di Jakarta. Pengumpulan data dilakukan dengan menyebarkan kuesioner secara online (Google Form). Analisis yang digunakan adalah Structural Equation Modeling (SEM) dengan menggunakan SmartPLS 3 sebagai alat untuk menganalisis data. Hasil penelitian ini menunjukkan bahwa pengekspresian diri pada merek dan kepercayaan pada merek dengan kecintaan pada merek sebagai variabel mediasi secara signifikan mempengaruhi pemasaran merek dari Mulut ke Mulut. Penelitian ini dapat digunakan sebagai masukan bagi Vans dalam meningkatkan E-WOM dari merek produk yang dijual .
\end{abstract}

Kata Kunci: ekspresi diri, kepercayaan merek, kecintaan merek , E-WOM

\begin{abstract}
The purpose of this study is to examine and determine the influence of Self-Expression and Brand Trust on Electronic Word of Mouth with Brand Love as a Mediation. The research design used in this study is a quantitative method with a descriptive approach. Sampling was carried out using a non-probability sampling method with a convenience sampling approach. Study as many as 100 respondents who are Vans consumers in Jakarta. Data collection is done by distributing questionnaires online (Google Form). The analysis used is Structural Equation Modeling (SEM) using SmartPLS 3 as a tool for analyzing data. Findings in this research showed that SelfExpression and Brand Trust with Brand Love as a mediation significantly affect Electronic Word of Mouth. This research can be used as input for Vans in increasing the E-WOM of the product brand being sold.
\end{abstract}

Keywords: Self-Expression, Brand Trust, Brand Love, Electronic Word of Mouth .

\section{PENDAHULUAN}

\section{Latar Belakang}

Di era serba teknologi setiap orang dapat mengakses informasi secara cepat dan mudah dari berbagai website. Salah satu bentuk komunikasi yang sering digunakan dalam dengan memanfaatkan teknologi adalah electronic word of mouth (e-WOM). $e$-WOM memiliki pengaruh yang lebih besar karena kecepatan akses, mudah dijangkau. Situs atau web media sosial dianggap sebagai platform yang benar-benar tepat untuk E-WOM (Erkan \& Evans, 2014).EWOM tidak hanya melibatkan berita baik, namun juga bisa berita buruk. Artinya, tidak mempedulikan seberapa banyak dan baik iklannya, maka jika ada kepercayaan yang baik mengenai merek tertentu, tentu akan menyebarkan informasi pada pihak lain. Melalui kepercayaan akan merek tertentu pada seseorang konsumen, maka sangat wajar jika ada orang lain menanyakan pendapatnya menggunakan produk perusahaan atau merek tersebut, mereka 
akan menceritakan tentang segi positif produk tersebut hingga melalui Word of Mouth (WOM) yang berkembang di masyarakat. Hal inilah yang diperlukan bagi industri apapun yang memiliki persaingan yang cukup ketat antar pelaku bisnisnya. Electronic-word of mouth dapat dipengaruhi oleh beberapa variabel yaitu self-expression, brand trust dan brand love. Wallace, Buil dan Chernatony (2014) menyimpulkan kecintaan pelanggan pada merek mempunyai pengaruh positif terhadap elecetronic-word of mouth. Cinta merek dianggap sebagai masukan penting dari keterlibatan aktif, E-WOM. Suatu studi menggunakan cinta merek - mengarah pada aktif keterlibatan yang bergantung pada kepercayaan merek dan ekspresi diri. Sementara itu ekspresif diri terhadap suatu merek dinyatakan sebagai persepsi konsumen tentang bagaimana merek tertentu dapat meningkatkan atau mencerminkan diri sosial atau batin mereka (Marquetto et al.,2017). Penelitian ini mencoba untuk mengeksplorasi pengaruh ekspresi diri terhadap kecintaan merek,dan untuk menggambarkan dampak kecintaan merek pada keterlibatan aktif untuk menceritakan merek pada orang lain. Hasil penelitian yang dilakukan oleh Karjaluoto, Munnukka dan Kiuru (2016) menyimpulkan brand love memiliki efek yang sangat positif terhadap electronic-word of mouth. Rageh dan Spinelli (2012) menyimpulkan bahwa kecintaan pelanggan pada suatu produk mempunyai pengaruh positif terhadap electronic-word of mouth. Wallace, Buil, dan Chernatory (2014) menyimpulkan kecintaan pelanggan pada merek membawa dampak positif terhadap electronic-word of mouth.

Electronic-word of mouth pada penelitian ini mengkaji konsumen sepatu merek Vans dengan beberapa variabel yang terkait dengan prilaku E-WOM adalah self-expression, yang mencakup tentang persepsi diri konsumen merek Vans, brand trust yang mencakup penilaian secara subjektif dan emosional dari konsumen setelah menggunakan sepatu Vans dan pikiran konsumen dalam mengekspresikan dirinya dengan sepatu Vans, serta brand love yang mencakup kecintaan konsumen terhadap sepatu Vans. Varibel yang terkait tersebut mengadopsi dari penelitian sebelumnya, dimana meskiun banyak penelitian telah dilakukan tentang E-Wom. Masih ditemukan banyak perbedaan. Perbedaan penelitian ini dengan penelitian sebelumnya adalah pada objek, tempat dan subjek penelitian. Penelitian ini dilakukan sepatu merek Vans, dengan konsumen yang berada di Jakarta. Untuk itu masih perlu dilakukan penelitian lebih lanjut dalam upaya mengintegrasikannya satu kerangka konseptual dari varivbel E-Wom. self-expression, brand trust dan brand love, dan inilah menjadi kontribusi dari penelitian ini.

\section{Rumusan Masalah}

1. Apakah self-expression memiliki pengaruh positif terhadap brand love?

2. Apakah brand trust memiliki pengaruh positif terhadap brand love?

3. Apakah brand love memiliki pengaruh positif terhadap electronic-word of mouth?

4. Apakah self-expression memiliki pengaruh positif terhadap electronic-word of mouth?

5. Apakah brand trust memiliki pengaruh positif terhadap electronic-word of mouth ?

\section{Self-Expression}

Karjaluoto, Munnukka dan Kiurru (2016) mendefinisikan self-expression sebagai bagaimana konsumen benar-benar menganggap dirinya sendiri dan diri yang dia cita-citakan dalam merek tersebut. Batra (2012) mendefinisikan self-expression sebagai bagaimana konsumen menggambarkan merek yang mereka cintai dalam hal memiliki fitur dan karakteristik yang serupa dengan diri mereka sendiri. Banister dan Hogg (2004) mendefinisikan self-expression sebagai cara konsumen mengekspesikan diri mereka terhadap merek yang nyaman bagi mereka. Dapat disimpulkan bahwa self-expression adalah bagaimana cara konsumen mengekspresikan diri mereka sendiri terhadap merek yang memiliki ciri-ciri yang sesuai dengan diri mereka sehingga serupa dengan diri mereka sendiri. 


\section{Brand Trust}

Chaudhuri dan Holbrook (2001:82) mendefinisikan kepercayaan sebagai kemauan konsumen untumengandalkan kemampuan merek untuk melakukan fungsinya. Morgan dan Hunt (1994) mendefinisikan kepercayaan sebagai kesediaan konsumen untuk bergantung pada harapan mereka tentang merek perusahaan di masa depan. Hawass (2013:87) mendefinisikan brand trust sebagai pelanggan secara emosional dan rasional melekat pada nama merek tertentu. Doney dan Cannon (1997:37) mendefinisikan brand trust sebagai kepercayaan berdasarkan kemampuan suatu merek dan pihak yang terus memenuhi kewajibannya sebagai merek. Dapat disimpulkan bahwa brand trust adalah pelanggan akan merasa aman menggunakan suatu merek karena sudah memiliki kepercayaan terhadap merek tersebut dan dapat mengandalkan merek tersebut dalam memenuhi kewajibannya sebagai merek.

\section{Brand Love}

Ahuvia (1993) mendefinisikan brand love adalah saat merek mencapai tingkat integrasi nyata dan perasaan yang diinginkan oleh konsumen, maka konsumen merasakan cinta untuk merek tersebut. Albert dan Merunka (2013) mendefinisikan brand love sebagai bagian yang terintegrasi dari ekspesi diri konsumen dengan menggunakan merek tertentu dan menunjukkan rasa cintanya pada merek tersebut.

Carroll dan Ahuvia (2006) mendefinisikan brand love sebagai tingkat ketertarikan emosional kuat yang dimiliki konsumen yang puas dengan merek tersebut. Arnett (2003) mendefinisikan brand love sebagai bentuk perasaan memiliki dan mengekspresikan diri sendiri terhadap merek tersebut, serta menciptakan kebutuhan yang dibutuhkan dari merek tersebut.

Berdasarkan penjelasan diatas, dapat disimpulkan bahwa brand love adalah perasaan yang diinginkan oleh konsumen saat mencapai tingkat integrasi yang nyata dan dapat mengekspresikan diri nya atas kecintaannya terhadap merek tersebut sehingga menimbulkan kebutuhan dari merek tersebut.

\section{Electronic-Word of Mouth}

Hennig, Gwinner, Wallsh dan Gremler (2004) mendefinsikan electronic-word of mouth sebagai pernyataan positif atau negatif yang dibuat oleh calon, pelanggan aktual atau mantan tentang suatu produk atau perusahaan, yang disediakan melalui saluran offline atau online. Wu dan Wang (2011) mendefinisikan electronic-word of mouth sebagai komunikasi lisan satu orang dengan yang lainnya antara penerima dan pengirim, yang melibatkan merek tersebut. HennigThurau dkk. (2004 dalam Mohammed Abubakar, A, 2016) menndefinisikan electronic-word of mouth sebagai bentuk penyataan positif atau negative yang dibuat oleh pelanggan potensial, actual, atau mantan pelanggan tentang merek yang tersedia bagi banyak orang dan institusi melalui internet.

Berdasarkan penjelasan diatas, dapat disimpulkan bahwa electronic-word of mouth adalah pernyataan positif atau negatif yang dibuat oleh calon, pelanggan aktual atau mantan tentang suatu produk atau perusahaan dari penerima kepada pengirim, yang disediakan melalui saluran online. 


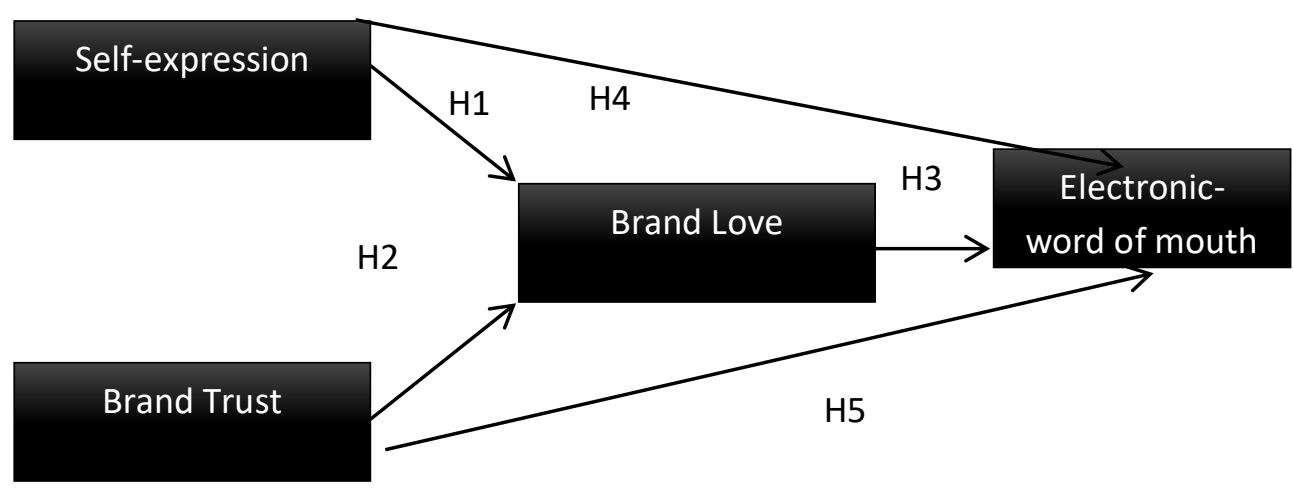

Gambar 1. Model Penelitian

Hipotesis penelitian ini adalah sebagai berikut:

Hipotesis 1: Self-expression memiliki pengaruh positif terhadap brand love.

Hipotesis 2: Brand trust memiliki pengaruh positif terhadap brand love.

Hipotesis 3: Brand love memiliki pengaruh positif terhadap electronic-word of mouth.

Hipotesis 4: Self-expression memiliki pengaruh positif terhadap electronic word of mouth.

Hipotesis 5 : Brand trust memiliki pengaruh positif terhadap electronic word of mouth

\section{METODE PENELITIAN}

Populasi penelitian adalah seluruh konsumen Vans yang berlokasi di Jakarta. Penelitian ini menggunakan teknik convenience sampling, dengan alasan adanya ketersediaan dan kesediaan responden saat penelitian ini dilakukan. Jumlah sampel yang diteliti sebanyak 100 responden. Teknik pengumpulan data menggunakan kuesioner. Kuesioner disebarkan secara online menggunakan Google Form kepada responden yang merupakan konsumen Vans di Jakarta. Dalam penelitian ini variabel yang diteliti meliputi: self-expression, diukur menggunakan 5 item yaitu: Mencerminkan kepribadian; Mencerminkan apa yang ada didalam diri; Berkontribusi terhadap gaya hidup; Menaikkan pandangan orang lain tentang diri dan Memberikan pandangan yang positif terhadap diri. Variable brand trust menggunakan 5 item: Merupakan merek yang bisa dipercayan; Merupakan merek yang bisa diandalkan; Merupakan merek yang jujur; Merupakan merek yang aman untuk digunakan dan Merupakan merek yang memenuhi harapan. Untuk mengukur variabel Electronic-word of mouth 5 item yaitu: Review secara online membuat konsumen percaya diri untuk membeli produk; Review secara online membantu konsumen memilih produk yang bagus; Berbicara hal-hal positif mengenai produk; Merekomendasikan produk ke orang lain; Merekomendasikan produk ke teman/kerabaat. Untuk mengukur variabel Brand love. 5 item yaitu Merupakan merek yang bagus, Menggunakan merek tersebut membuat konsumen sangat gembira; Produk menimbulkan rasa percaya diri pada konsumen; Mempunyai perasaan terikat dengan merek; Memiliki rasa suka terhadap merek Pengolahan data penelitian menggunakan software PLS-SEM yang terdiri dari dua analisis yaitu outer model dan inner model.

\section{HASIL DAN PEMBAHASAN Profil Responden}

Berdasarkan dara karakteristik responden, mayoritas responden adalah responden laki-laki (56\%) dengan rentan usia antara 21-25 tahun (58\%) dan berdomisili di Jakarta Barat (35\%). 


\section{Outer Model}

Berdasarkan analisis hasil model pengukuran (Outer Model Analysis) ditemukan bahwa semua indikator yang digunakan untuk mengukur variabel-variabel penelitian bersifat valid dan reliable sehingga dapat merepresentasikan variabel-variabel penelitian dan dapat dipercaya dan diandalkan.

a. Convergent Validity (Validitas Konvergen)

Tabel 1

Hasil Nilai AVE

Variabel

Average Extracted Variance (AVE)

\begin{tabular}{cl}
\hline Self-Expression & 0.553 \\
\hline Brand Trust & 0.529 \\
\hline Brand Love & 0.562 \\
\hline Electronic-word of mouth & 0.541 \\
\hline
\end{tabular}

Diketahui bahwa nilai AVE dari masing masing variabel memiliki nilai diatas 0,5 yang telah memenuhi kriteria convergent validity yang diukur dari nilai AVE. Hal ini menunjukkan bahwa variabel-variabel pada penelitian ini telah memenuhi kriteria.

\section{b. Discriminant Validity (Validitas Diskriminan)}

Tabel 2

Hasil Analisis Cross Loading

\begin{tabular}{ccccc}
\hline Indikator & Self-Expression & Brand Trust & Brand Love & EWOM \\
\hline SE1 & $\mathbf{0 . 6 1 8}$ & 0.325 & 0.407 & 0.381 \\
\hline SE2 & $\mathbf{0 . 8 7 9}$ & 0.636 & 0.746 & 0.664 \\
\hline SE3 & $\mathbf{0 . 7 6 9}$ & 0.561 & 0.629 & 0.595 \\
\hline SE4 & $\mathbf{0 . 6 6 9}$ & 0.430 & 0.478 & 0.490 \\
\hline SE5 & $\mathbf{0 . 7 2 6}$ & 0.591 & 0.527 & 0.589 \\
\hline BT1 & 0.388 & $\mathbf{0 . 6 1 3}$ & 0.306 & 0.414 \\
\hline BT2 & 0.586 & $\mathbf{0 . 8 4 0}$ & 0.701 & 0.639 \\
\hline BT3 & 0.512 & $\mathbf{0 . 7 1 8}$ & 0.464 & 0.471 \\
\hline BT4 & 0.568 & $\mathbf{0 . 7 1 0}$ & 0.526 & 0.585 \\
\hline BT5 & 0.470 & $\mathbf{0 . 7 3 8}$ & 0.582 & 0.512 \\
\hline BL2 & 0.643 & 0.587 & $\mathbf{0 . 8 4 5}$ & 0.637 \\
\hline BL3 & 0.627 & 0.638 & $\mathbf{0 . 7 6 1}$ & 0.643 \\
\hline BL4 & 0.471 & 0.424 & $\mathbf{0 . 6 7 3}$ & 0.442 \\
\hline BL5 & 0.539 & 0.524 & $\mathbf{0 . 7 1 0}$ & 0.526 \\
\hline EWOM1 & 0.351 & 0.330 & 0.283 & $\mathbf{0 . 5 5 3}$ \\
\hline EWOM2 & 0.605 & 0.616 & 0.685 & $\mathbf{0 . 7 3 4}$ \\
\hline EWOM3 & 0.441 & 0.471 & 0.443 & $\mathbf{0 . 6 8 1}$ \\
\hline EWOM4 & 0.605 & 0.537 & 0.597 & $\mathbf{0 . 8 4 0}$ \\
\hline EWOM5 & 0.654 & 0.653 & 0.663 & $\mathbf{0 . 8 3 2}$ \\
\hline
\end{tabular}

Diketahui bahwa nilai loadings dari masing masing indikator setiap variabel lebih besar nilai loadings variabel lainnya. Hal ini menunjukkan bahwa indikator-indikator tersebut telah memenuhi kriteria discriminant validity yang diukur dari nilai cross loadings. 


\section{c. Composite Reliability}

Tabel 3

Hasil Analisis Reliabilitas

\begin{tabular}{|c|c|c|c|}
\hline Variabel & Indikator & Loading (>0.4) & Composite Reability \\
\hline \multirow[t]{5}{*}{ Self-Expression } & SE1 & 0.618 & \multirow[t]{5}{*}{0.859} \\
\hline & SE2 & 0.879 & \\
\hline & SE3 & 0.769 & \\
\hline & SE4 & 0.669 & \\
\hline & SE5 & 0.726 & \\
\hline \multirow[t]{5}{*}{ Brand Trust } & BT1 & 0.613 & \multirow[t]{5}{*}{0.848} \\
\hline & BT2 & 0.840 & \\
\hline & BT3 & 0.718 & \\
\hline & BT4 & 0.710 & \\
\hline & BT5 & 0.738 & \\
\hline \multirow[t]{4}{*}{ Brand Love } & BL2 & 0.845 & \multirow[t]{4}{*}{0.836} \\
\hline & BL3 & 0.761 & \\
\hline & BL4 & 0.673 & \\
\hline & BL5 & 0.710 & \\
\hline \multirow[t]{5}{*}{ EWOM } & EWOM1 & 0.553 & \multirow[t]{5}{*}{0.852} \\
\hline & EWOM2 & 0.734 & \\
\hline & EWOM3 & 0.681 & \\
\hline & EWOM4 & 0.840 & \\
\hline & EWOM5 & 0.832 & \\
\hline
\end{tabular}

Composite reliability dari semua variabel berada diatas 0.6 dan seluruh indikator memiliki loading factor di atas 0.4. hal ini dapat disimpulkan bahwa variabel-variabel yang digunakan dalam penelitian ini adalah reliabel.

\section{Inner Model}

\section{a. Uji Koefisien Determinasi $\left(\mathbf{R}^{\mathbf{2}}\right)$}

Koefisien determinasi digunakan untuk mengetahui besarnya kontribusi variabel independen terhadap variabel dependen. Dalam penelitian ini, nilai koefisien determinasi diperoleh dari variabel kepercayaan merek dan pengekspresian diri yang mempengaruhi kecintaan pada merek dan variabel Self-Expression, Brand Trust dan Brand Love yang mempengaruhi electronic word of mouth. Hasil koefisien determinasi akan disajikan dalam tabel berikut ini.

Tabel 4

Hasil Koefisien Determinasi

\begin{tabular}{|c|c|}
\hline Variabel & R-Square \\
\hline Brand Love & 0.665 \\
\hline EWOM & 0.675 \\
\hline
\end{tabular}

Berdasarkan hasil koefisien determinasi pada Tabel 4, dapat diketahui nilai R-Square pada variabel Brand Love adalah sebesar 0.665 yang berarti sebesar 66,5\% variabel Brand Love dapat dijelaskan oleh Self-Expression dan Brand Trust, sedangkan sisanya 33,5\% (100\%-66,5\%) dijelaskan oleh variabel variabel lainnya yang tidak termasuk dalam model penelitian ini. Nilai $R$-Square pada variabel EWOM adalah sebesar 0.675 yang berarti sebesar $67,5 \%$ variabel 
EWOM dapat dijelaskan oleh Self-Expression, Brand Trust dan Brand Love sedangkan sisanya 32,5\% (100\%-67,5\%) dijelaskan oleh variabel-variabel lainnya yang tidak termasuk dalam model penelitian ini. Berdasarkan kriteria nilai R-Square yang dikemukakan oleh Hair et al. (2011), kedua nilai R-Square berada diantara 0,26 dan 0,74 yang artinya tergolong moderat.

\section{b. Uji Path Coefficient}

Menurut Sholiha (2015), bootstrap adalah alat yang digunakan untuk meminimalkan tidak andalnya hubungan dengan kesalahan penggunaan distribusi normal dan penggunanya.

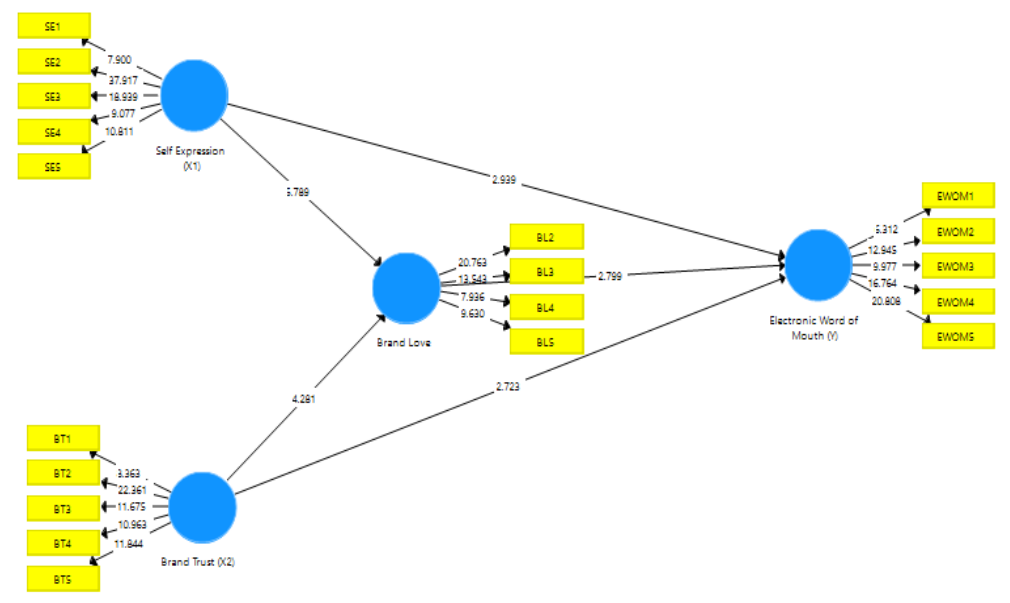

Gambar 2

Hasil Bootstrapping

Dari Gambar 2 dapat dilihat bahwa keseluruhan variabel memiliki path coefficient dengan angka yang positif, yang mengindikasikan bahwa pengaruh antar variabel searah, yakni variabel selfexpression terhadap variabel brand love bernilai positif sebesar 0.498 , kemudian variabel selfexpression terhadap electronic-word of mouth bernilai positif sebesar 0.296, variabel brand trust terhadap brand love bernilai positif sebesar 0.385, kemudian variabel brand trust terhadap electronic-word of mouth bernilai positif sebesar 0.287, dan variabel brand love terhadap electronic-word of mouth bernilai positif sebesar 0.322 .

Uji Hipotesis (Uji t-statistik)

\section{Tabel 5}

Hasil Uji Hipotesis

\begin{tabular}{|l|l|l|l|}
\hline Variabel & $\begin{array}{l}\text { Original Sample } \\
(\mathrm{O})\end{array}$ & T Statistics & P Values \\
\hline SE - BL & 0.498 & 6.026 & 0.000 \\
\hline BT - BL & 0.385 & 4.432 & 0.000 \\
\hline BL - EWOM & 0.322 & 3.028 & 0.003 \\
\hline SE - EWOM & 0.296 & 3.174 & 0.002 \\
\hline BT - EWOM & 0.287 & 2.654 & 0.008 \\
\hline
\end{tabular}

Pengujian Hipotesis 1: Pengaruh self-expression terhadap brand love positif dan signifikan, artinya $\mathrm{H} 1$ tidak ditolak.

Pengujian Hipotesis 2 : Pengaruh brand trust terhadap brand love positif dan signifikan, artinya $\mathrm{H} 2$ tidak ditolak.

Pengujian Hipotesis 3: Pengaruh brand love terhadap electronic-word of mouth positif dan signifikan, artinya $\mathrm{H} 3$ tidak ditolak. 
Pengujian Hipotesis 4 : Pengaruh self-expression terhadap electronic-word of mouth positif dan signifikan, artinya $\mathrm{H} 4$ tidak ditolak.

Pengujian Hipotesis 5 : Pengaruh brand trust terhadap electronic-word of mouth positif dan signifikan, artinya H5 tidak ditolak.

\section{Diskusi}

Pada pengujian hipotesis menunjukkan bahwa hipotesis 1 didukung, yang berarti bahwa variabel Self-Expression memiliki pengaruh positif terhadap variabel Brand Love. Hal ini menunjukkan bahwa semakin tinggi tingkat Self-Expression maka akan meningkatkan Brand Love dari produk tersebut. Hasil penelitian ini sejalan dengan penelitian sebelumnya (Karjaluoto, Munnukka dan Kiuru , 2016 ; Albert dan Merunka , 2013). Hipotesis 2 didukung yang menunjukkan bahwa variabel Brand Trust memiliki pengaruh positif terhadap variabel Brand Love. Hal ini menunjukkan semakin tinggi tingkat Brand Trust maka akan meningkatkan Brand Love dari produk tersebut. Hasil penelitian ini sejalan dengan penelitian sebelumnya (Karjaluoto, Munnukka dan Kiuru, 2016 ; Leventhal,Wallace, Build and Chernatony, 2014; Wallace, Build dan Chernatony , 2017). Hipotesis 3 didukung yang menunjukkan bahwa variabel Brand Love memiliki pengaruh positif terhadap variabel electronic word of mouth. Hal ini menunjukkan semakin tinggi tingkat Brand Love akan meningkatkan electronic-word of mouth pada produk tersebut. Hal ini sejalan dengan penelitian sebelumnya (Karjaluoto, Munnukka dan Kiuru , 2016 ; Wallace, Buil dan Chernatony , 2014 ; Rageh dan Spinelli , 2012) . Hipotesis 4 didukung yang menunjukkan bahwa variable Self-Expression memiliki pengaruh positif terhadap variabel electronic-word of mouth. Hal ini menunjukkan semakin tinggi tingkat Self-Expression akan meningkatkan electronic word of mouth pada produk tersebut. Hal ini sejalan dengan penelitian sebelumnya (Loureiro dan Kaufmann , 2018 ; Karjaluoto, Munnukka dan Kiuru , 2016). Hipotesis 5 didukung yang menunjukkan bahwa variable Brand Trust memiliki pengaruh positif terhadap variable electronic word of mouth. Hal ini menunjukkan semakin tinggi tingkat Brand Trust akan meningkatkan electronic-word of mouth pada produk tersebut . Hal ini sejalan dengan penelitian sebelumnya Perez 2019 ; Abubakar , 2016 )

\section{KESIMPULAN}

1. Self-Expression memiliki pengaruh positif terhadap Brand Love pada konsumen Vans di Jakarta. Semakin tinggi tingkat Self-Expression maka akan meningkatkan Brand Love dari produk tersebut.

2. Brand Trust memiliki pengaruh positif terhadap Brand Love pada konsumen Vans di Jakarta. Semakin tinggi tingkat Brand Trust maka akan meningkatkan Brand Love dari produk tersebut.

3. Brand Love memiliki pengaruh positif terhadap Electronic-word of mouth pada konsumen Vans di Jakarta. Semakin tinggi tingkat Brand Love akan meningkatkan electronic-word of mouth pada produk tersebut.

4. Self-Expression memiliki pengaruh positif terhadap Electronic-word of mouth pada konsumen Vans di Jakarta. Semakin tinggi tingkat Self-Expression akan meningkatkan electronic word of mouth pada produk tersebut.

5. Brand Trust memiliki pengaruh positif terhadap Electronic-word of mouth pada konsumen Vans di Jakarta. Semakin tinggi tingkat Brand Trust akan meningkatkan electronic word of mouth pada produk tersebut. 


\section{Ucapan Terima Kasih}

Terima kasih kami ucapkan pada Lembaga Penelitian dan Pengabdian Kepada Masyarakat Universitas Tarumanagara yang telah memberikan pendanaan dalam penelitian ini melalui skema hibah penugasan tugas akhir skripsi.

\section{REFERENSI}

Abubakar, M. A. (2016). Does eWOM influence destination trust and travel intention: A medical tourism perspective: Znanstveno-strucni casopis znanstveno-strucni casopis. Ekonomska Istrazivanja, 29(1)

Ahuvia, A.C. (1993), "I love it! Towards a unifying theory of love across diverse love objects", $\mathrm{PhD}$ dissertation, Northwestern University, Evanston, IL.

Albert, N. and Merunka, D. (2013), "The role of brand love in consumer-brand relationships", Journal of Consumer Marketing, Vol. 30 No. 3, pp. 258-266.

Arnett, D.B., German, S.D. and Hunt, S.D. (2003), "The identity salience model of relationship marketing success: Journal of Product \& Brand Management the case of nonprofit marketing", Journal of Marketing, Vol. 67 No. 2, pp. 89-105.

Batra, R., Ahuvia, A. and Bagozzi, R.P. (2012), "Brand love", Journal of Marketing, Vol. 76 No. 2, pp. 1-16.

Banister, E.N. and Hogg, M.K. (2004), 'Negative symbolic consumption and consumers' drive for self-esteem: the case of the fashion industry", European Journal of Marketing, Vol. 38 No. 7, pp. 850-868.

Becerra, E. P., \& Badrinarayanan, V. (2013). The influence of brand trust and brand identification on brand evangelism. The Journal of Product and Brand Management, 22(5), 371-383.

C. Leventhal, R., Wallace, E., Buil, I. and de Chernatony, L. (2014), "Consumer engagement with self-expressive brands: brand love and WOM outcomes", Journal of Product \& Brand Management, Vol. 23 No. 1, pp. 33-42.

Carroll, B.A. and Ahuvia, A.C. (2006), "Some antecedents and outcomes of brand love", Marketing Letters, Vol. 17 No. 2, pp. 79-89.

Chaudhuri, A., \& Holbrook, M. B. (2001). The chain of effects from brand trust and brand affect to brand performance: The role of brand loyalty. Journal of Marketing, 65(2), 81-93.

Doney, P.M. and Cannon, J.P. (1997), “An examination of trust in buyer-supplier relationships", Journal of Marketing, Vol. 61 No. 2, pp. 35-51.

Erkan, I., \& Evans, C. (2014). The impacts of electronic word of mouth in social media on consumers' purchase intentions. In Proceedings of the International conference on digital marketing (ICODM2014) pp. 9e14

Hamid Hawass, H. (2013), "Brand trust: implications from consumer doubts in the Egyptian mobile phone market", Journal of Islamic Marketing, Vol. 4 No. 1, pp. 80-100.

Hennig-Thurau, T., Gwinner, K.P., Walsh, G. and Gremler, D.D. (2004), "Electronic word-ofmouth via consumer- opinion platforms: what motivates consumers to articulate themselves on the internet?", Journal of Interactive Marketing, Vol. 18 No. 1, pp. 38-52.

Huaman-Ramirez, R. and Merunka, D. (2019), "Brand experience effects on brand attachment: the role of brand trust, age, and income", European Business Review, Vol. 31 No. 5, pp. 610-645.

Jalilvand, M. R., Nasrolahi Vosta, L., Kazemi Mahyari, H., \& Khazaei Pool, J. (2017). Social responsibility influence on customer trust in hotels: Mediating effects of reputation and word-of-mouth. Tourism Review of AIEST - International Association of Scientific Experts in Tourism, 72(1), 1-14. 
Karjaluoto, H., Munnukka, J. and Kiuru, K. (2016), "Brand love and positive word of mouth: the moderating effects of experience and price", Journal of Product \& Brand Management, Vol. 25 No. 6, pp. 527-537

Kaufmann, H. R., Loureiro, S. M. C., \& Manarioti, A. (2016). Exploring behavioural branding, brand love and brand co-creation. Journal of Product and Brand Management, 25(6),

Morgan, RM dan Hunt, SD (1994), "Teori komitmen-kepercayaan dari hubungan pemasaran", jurnal Pemasaran, Vol. 58 No 3, pp. 20-38. 516-526. https://doi.org/10.1108/JPBM-062015-0919

Marquetto, M. F. and Pinto, N. G. and Grohmann, M. Z. and Battistella, L. F. (2017) Knowing the Fans Behaviour in Relation To Love of Football Clubs Brands. Brazilian business review. 14.3.1.

Rageh Ismail, A. and Spinelli, G. (2012), "Effects of brand love, personality and image on word of mouth", Journal of Fashion Marketing and Management, Vol. 16 No. 4, pp. 386-398.

Rebwar, K. G., Garcia-Perez, A., Dibb, S., \& Iskoujina, Z. (2019). Trust and reciprocity effect on electronic word-of-mouth in online review communities. Journal of Enterprise Information Management, 33(1), 120-138.

Wallace, E., Buil, I. and de Chernatony, L. (2014), "Consumers' self-congruence with a "Liked" brand", European Journal of Marketing, Vol. 51 No. 2, pp. 367-390.

$\mathrm{Wu}, \mathrm{P}$. and Wang, Y. (2011), "The influences of electronic word-of-mouth message appeal and message source credibility on brand attitude", Asia Pacific Journal of Marketing and Logistics, Vol. 23 No. 4, pp. 448-472. 